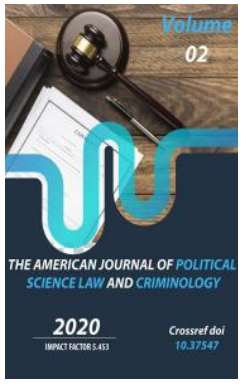

Copyright: Original content from this work may be used under the terms of the creative commons attributes 4.0 licence.

\section{Emergence Of State Policy, Legal And Regulatory Framework And Institutional System For Radical Modernization Of The Tax System In Uzbekistan}

\author{
Akhmadjon Haydarovich Khudayorov \\ Senior Lecturer Of The Department Philosophical And Socio-Political Sciences \\ Faculty Of Construction Management Tashkent Institute Of Architecture And Civil Engineering \\ Tashkent, Uzbekistan
}

\title{
ABSTRACT
}

This article deals with the formation of the legal and regulatory framework of the tax system in Uzbekistan in 1991-2019 and the stages of its improvement.

\section{KEYWORDS}

Tax, budget, tax policy, tax legislation, taxpayer, income, tax authorities, Tax Code, tax burden, tax benefits, legal regulations.

\section{INTRODUCTION}

From the first days of independence, Uzbekistan has paid great attention to the creation of an effective tax system and considered this issue as the most important factor in ensuring the success of socioeconomic reforms.

After gaining independence, when the independent choice of the market path was required, Uzbekistan faced the need to radically update the legislation, including in the economic sphere, in accordance with the tasks of radical economic and social change. Special attention had to be paid to the development of tax legislation. This, of course, requires a wellthought-out, clear and understandable longterm tax system [1]. 


\section{THE MAIN RESULTS AND FINDINGS}

This means that its own model of economic reform cannot simply be copied from the tax legislation of other countries where market relations are developed and even prosperous. In the transition period, the old tax system could not be suddenly lost. Because in that case, the state would be left without income and the whole society would suffer without being able to perform its duties. The effective implementation of tax policy depends in many respects on the strength of its legal framework. Tax legislation on tax policy plays an important role in this.

According to Doctor of Economics I.M.Niyazmetov, for the effective functioning of the tax system of any country, tax legislation must be well developed. In this case, in particular, the general principles of tax legislation, in particular, the basic concepts such as taxes, tax system, taxpayers, must be conveyed to taxpayers in a fully descriptive manner [2].

According to the experience of developed countries around the world, the stability of the tax system requires that tax legislation be unchanged to the extent that businesses can plan their activities in the medium and long term. For example, in the European Union, the United States, Canada, Japan, Switzerland, as well as in rapidly developing China, India, Brazil, Turkey, South Korea, Singapore and many other countries, the basic elements of the tax system are relatively stable and guaranteed by legal regulations [3].

The legal basis of the tax policy of the Republic of Uzbekistan is strengthened by the Constitution of the Republic of Uzbekistan [4], tax laws, decrees, codes, resolutions and other by-laws.

Achieving independence in the field of taxation Before the declaration of independence of our country, that is, on February 15, 1991, the Law of the Republic of Uzbekistan "On Taxes on Enterprises, Associations and Organizations" [5] was adopted [6].

The main purpose of the law is to determine the sources of tax revenues of the state budgets and local budgets of Uzbekistan and the Republic of Karakalpakstan and to ensure the financial base of state social guarantees, to regulate business activities of legal entities, to make international payments on a centralized basis, provision of financial resources, as well as stabilization of foreign exchange circulation in the territory of the Republic of Uzbekistan, promotion of economical use of natural resources and protection of the environment.

The law establishes the general procedure for resolving disputes arising in the territory of the Republic of Uzbekistan on taxes, taxpayers, objects of taxation, the order of payment of taxes, tax benefits, liability for violation of the law and the payment of taxes.

In accordance with the law, enterprises, associations and organizations engaged in entrepreneurial and other activities that generate income are required to pay the following taxes in the territory of the Republic of Uzbekistan:

- $\quad$ Corporate income tax;

- $\quad$ Value added tax;

- $\quad$ Excise tax;

- $\quad$ Property tax on enterprises;

- $\quad$ Tax on the use of mineral resources [7] 
This law consists of Chapter 9, Article 44, and the fact that the tax legislation did not meet the requirements of the transition period led to more than 90 amendments and additions during 1991-1997 [8].

As tax legislation is one of the most important areas for state independence, it is included as a separate article in the Law of the Republic of Uzbekistan on the Foundations of State Independence. In particular, Article 12 stipulates that "taxes and fees levied on the territory of the Republic shall be transferred to the State Budget of the Republic of Uzbekistan and local budgets.

This determined that the state would pursue an independent tax policy and that the fees would go to the budget. Article 51 of the Constitution of the Republic of Uzbekistan stipulates that citizens are obliged to pay taxes and local fees established by law. It has a single tax system in the territory of the Republic of Uzbekistan. Only the Oliy Majlis has the right to impose taxes and other mandatory payments.

Lack of experience in creating tax legislation in the transition to market relations, the fact that in a very short time the democratic system requires the development of taxes for enterprises and organizations with different forms of ownership, the apparent unsatisfactory performance necessitated the adoption of a separate tax code.

On April 24, 1997, the Law of the Republic of Uzbekistan "On Approval of the Tax Code of the Republic of Uzbekistan" № 396-I and the Resolution of the Oliy Majlis of the Republic of Uzbekistan № 397-I were published. The Tax Code of the Republic of Uzbekistan was approved by the Oliy Majlis. According to this decision, the Tax Code of the Republic of
Uzbekistan came into force on January 1, 1998 [10].

The draft Tax Code, prepared in 1997, reflects the experience of the tax authorities of the republic, the analysis of world practice. He brought the tax laws of the republic and, consequently, the tax system closer to the level of developed countries. At the same time, it took into account the peculiarities of Uzbekistan's development.

The following principles and innovations can be seen in the draft Tax Code.

First, it made all the basic norms in the field of taxation a single document.

Second, a system of tax incentives has been introduced.

Third, it is planned to introduce an international system of accounting for income, value added of property and taxation, accounting for small and private business, simplification of reporting and calculations.

Fourth, the relationship of tax authorities with law enforcement agencies, credit institutions is clearly defined, the rights, duties and responsibilities of taxpayers and tax authorities are defined [11].

On April 24, 1997, the Tax Code of independent Uzbekistan was adopted for the first time in the form of Chapter 12, Article 122, which regulates relations in this area, types of taxes, collection procedure, scope of persons subject to tax benefits, as well as the rights and obligations of tax authorities. Although this code has been regulating tax relations for 10 years, it has not been able to define serious issues such as the legal status of taxpayers, the powers and obligations of state tax authorities, 
the objects of taxation and tax benefits, the rights and obligations of tax subjects.

The reason for the repeal of the Tax Code, adopted in 1998, was its inability to directly regulate tax relations, which underwent many (more than 500) changes [12].

Therefore, the government has set up a working group to study the current tax legislation and bring it closer to the best standards in the world.

The views of the UNDP experts were also taken into account. In particular, the proposals of expert Wayne Thirst, such as the removal of investment costs from the value added tax base, the introduction of a minimum amount of non-taxable income, were taken into account [13].

Taking into account the proposals of local and foreign experts and specialists, on December 25, 2007 the new Tax Code of the Republic of Uzbekistan was adopted, consisting of 2 (general and special) sections, 21 sections, 64 chapters and 392 articles [14].

The main difference of the new Tax Code from the previous one was that the new Tax Code was a document with direct effect. According to him, the procedure for calculating each type of tax is directly reflected in the Tax Code, without the implementation of various legal normative documents, instructions. Most importantly, it reflects the simplified taxation procedure, which is regulated on the basis of previous documents, and the procedure for calculating and collecting mandatory contributions to trust funds.

The document stipulates that tax legislation providing for changes in the rates of taxes and other mandatory payments must be published at least 1 month before the start of the reporting period and enter into force on the first day of the reporting period following the month in which they are officially published. The general part of the Tax Code defines the principles of taxation in accordance with international standards, the basic concepts used in the code, the procedures used to fulfill tax obligations, procedures for payment or deferral of taxes and mandatory payments, clear mechanisms for refunding overpayments. It also covered issues such as the forms of tax control and procedures for their implementation, as well as the procedure for appealing against the actions and inaction of tax officials, the establishment of liability for violations of tax legislation. It sets out clear principles of taxation that meet international standards and local conditions specific to our experience.

At the same time, the Code stipulates that the tax legislation provides for the payment of taxes and mandatory payments only if the taxpayers also determine the elements necessary for the calculation and payment of these taxes and mandatory payments. The Tax Code stipulates that all taxes and mandatory payments should be introduced only by legislation. At the same time, it is planned that the benefits for taxes and mandatory payments will be established by legislation and presidential decrees. We will see that by 2018 , more than 800 amendments have been made to the Tax Code in this new edition.

Despite the fact that it took exactly 3 years to develop the 2008 Tax Code, and amendments were allowed to improve it in another 2 years [16], we can see that this process has not yet been completed, but the tax legislation has become chronic. As a result, Uzbekistan was 
forced to update its Tax Code for the third time in its 30-year history. In this regard, the third revised Tax Code of the Republic of Uzbekistan was developed in 2019, and the new Tax Code came into force on January 1, 2020 [18].

The new Tax Code will gradually reduce the tax burden, simplify the tax system and improve tax administration, accelerate economic development and increase business and investment activity, create a healthy competitive environment. The code reflects the norms that serve to encourage honest, fair taxpayers, which are the backbone of the country's development, and to create conditions for the legitimate work of clandestine operators. The goal is not to evade taxes, but to make them interested in paying them on time. It was with these aspects in mind that the basic idea of creating a new tax system was based on key principles such as equality, simplicity, clarity and efficiency. With the adoption of this tax code, more than 120 new rules have been introduced in the tax system since January 1 this year. In particular, the types of taxes have been reduced from 13 to 9, and tax inspections will be conducted by the tax authorities only after the adoption of normative legal acts provided for in the Code and defining the procedure for their conduct. The responsibility of the tax authorities for the timely refund of overpaid or overcharged taxes has also been strengthened. The order of return of the amounts of overcharged taxes and financial sanctions, taking into account the interest accrued on the basis of the refinancing rate of the Central Bank in force during the period of collection (payment) of these amounts. The single social payment paid by enterprises with a state share of 50 percent or more has been reduced from 25 percent to 12 percent, and the VAT refund system has been radically changed. That is, after a detailed inhouse inspection, the right to return the "negative" VAT balance was granted [19].

\section{CONCLUSION}

The head of state is taking initiatives to transfer some of the powers of the President to the parliament, the executive branch and local governments. On the basis of such initiatives, the country has introduced the adoption of the state budget by law, abandoning the practice of adopting the state budget by presidential decree. One such initiative is reflected in the Tax Code. Until now, the granting of tax benefits was the sole prerogative of the President, but now such benefits are provided by the Tax Code. At the same time, the new version of the Tax Code increases the powers and responsibilities of local governments in the field of taxation.

In short, from the first years of independence, the reforms aimed at the formation of the legislation of the independent tax system began to be carried out consistently, and as a result of these reforms, the legislation of the tax system has been formed.

\section{REFERENCES}

1. Mirziyoev Sh.M. The consent of our people is the highest value given to our activities. Volume II. - Tashkent, Uzbekistan. 2019. - p 124.

2. Niyazmetov I.M. Ensuring the stability of the tax system by improving taxation mechanisms. Dissertation for the degree of Doctor of Economics (DSC)-Tashkent, 2018. -p94.

3. OECD Work on Taxation 2016-17. Center for Tax Policy and Administration / www.oecd.org/tax/; Fiscal Policy and Growth in Developing Asia / ADB 
Economics Working Paper

Series.№.412,2014.

4. Citizens are required to pay statutory taxes and local fees. Constitution of the Republic of Uzbekistan. - Tashkent, Uzbekistan. 2018. Article 51. - p 17. Only the Oliy Majlis has the right to introduce taxes and other mandatory payments. The Constitution of the Republic of Uzbekistan. - Tashkent, Uzbekistan. 2018. Article 78. -p. 28

5. In accordance with the Law of the Republic of Uzbekistan "On Amendments to the Constitution (Basic Law) of the Uzbek SSR" (364-XII №. 30.09.1991) in the title and text of this Law the words "Uzbek SSR" replaced. https://lex.uz/docs/139958

6. Bulletin of the Supreme Council of the Republic of Uzbekistan. 1991, issue 2.

7. About taxes levied on enterprises, associations and organizations. Law of the Republic of Uzbekistan. Tashkent, February 15, 1991. 2 pages. https://lex.uz/docs/134884

8. Yahyoev $\mathrm{K}$ noted that in the article "Tax laws should be long-term and stable" until 1995, six additions and changes were made. Taxes and customs notifications. 1995, №7 (31).

9. Constitution of the Republic of Uzbekistan. Tashkent. Uzbekistan. 2018. Article 78. 17-p, 28-p

10. Law of the Republic of Uzbekistan "On approval of the Tax Code of the Republic of Uzbekistan". Tashkent, April 24, 1997, №396-I.

https://lex.uz/pages/forpda.aspx?lact_id=9

0454

11. Gataulin Sh. The tax system of Uzbekistan: ways of formation and development. Journal of the Taxpayer, 1996, № 11, p.
12. Niyazmetov I.M. Ensuring the stability of the tax system by improving taxation mechanisms. Dissertation for the degree of Doctor of Economics (DSC)-Tashkent, 2018. -P 61.

13. Taxes and customs notifications. September 12, 2005. № 37 (581) Page 5

14. About approval of the Tax code of the Republic of Uzbekistan Law of the Republic of Uzbekistan. ORQ-136 № 25.12.2007. https://lex.uz/docs/1296979?ONDATE=08.0 1.2020

15. Developed on the basis of laws that are the basis for amendments and additions to the Tax Code.

16. After the adoption of the Decree of the President of the Republic of Uzbekistan № 2108 of January 7, 2005 "On the preparation of a new version of the Tax Code of the Republic of Uzbekistan", three years elapsed before the adoption of the Tax Code. The task was to ensure regular and comprehensive monitoring and analysis of its effectiveness and, if necessary, to make proposals for further improvement of some of its norms.

17. Decree of the President of the Republic of Uzbekistan dated February 13, 2018 № F5214 "On organizational measures to radically improve the tax legislation."

18. "People's Word" newspaper, December 31, 2019.

19. https://kun.uz/news/2020/01/11/ 